\title{
A NOTE ON QUEBEC ATTITUDES TOWARD CONSTITUTIONAL OPTIONS
}

\author{
Allan KORNBERG* \\ AND \\ KEITH ARCHER $\dagger$
}

I

\section{INTRODUCTION}

In a recent essay, Alan Cairns observed that the making of a new Canadian constitution has been an elite activity characterized by the assertion of blatant selfinterest on the part of key political actors and by strenuous attempts to manipulate public opinion in support of their respective interests. ${ }^{1}$ For example, the suggestion that popular referenda be used in constitutional amending procedures appears to have been motivated by self-interest and the tactical advantage this device might provide political elites, rather than by genuine concern over providing the public with an opportunity to express its policy preferences. Paradoxically, the electoral imperative-the need to harvest votes-appears to have led elected public officials at both levels of the federal system to curry favor with their constituents by representing themselves as their true "champions" despite an increasing contempt for their opinions. However, rather than focusing on their rhetoric or on their attempts to secure tactical advantages in the struggle over the new constitution, this paper examines public opinion on five possible constitutional arrangements: the status quo, renewed federalism, special status for Quebec, sovereignty association, and Quebec independence. Since the last three options have more than a modicum of support only in Quebec, the analysis is restricted to opinions in that province.

An examination of those opinions will indicate that the parameters structuring the debate over Quebec's future constitutional status have changed. The status quo no longer is a viable option. Instead, the choice is between moderate and radical change. The analysis also will indicate that variations in Québécois positions on constitutional options are most strongly associated with age, direction and intensity of provincial partisanship, degree of affection for the Canadian political community, extent of orientation to federal as opposed to provincial politics, and assessments of the relative costs and benefits of federalism to Quebec.

Two conclusions are drawn from the analyses. First, despite the ambiguity surrounding concepts such as special status, sovereignty association, and renewed

\footnotetext{
Copyright (C) 1983 by Law and Contemporary Problems.

* Professor of Political Science, Duke University.

† Department of Political Science, Duke University.

1. Cairns, Constitution-Mating, Govemment Self-Interest and the Problem of Legitimacy in Canada, in POLITical Support in Canada: The Crisis Years (forthcoming).
} 
federalism, the Quebec electorate appears to have become increasingly knowledgeable about these concepts in the period between the May 1979 national election and the May 1980 Quebec Referendum on Sovereignty Association. Second, despite the enactment of a new constitution, the constitutional crisis is likely to continue because the strongest support for options such as sovereignty association or outright independence for Quebec comes from a segment of Quebec's population which is likely to remain an important part of the electorate in the foreseeable future.

II

\section{Measures AND Methods}

The data presented in this paper are derived from the May 1979 national election study and a special referendum study conducted by Harold Clarke and his associates in May $1980 .^{2}$ The analysis proceeds in two stages. In the first stage, the 1979 and 1980 distributions of Québécois positions on the five constitutional options are cross-tabulated with their ethnicity, age, direction and intensity of provincial partisanship, socioeconomic status, and level of education.

Analyses of bivariate relationships such as are conducted in stage one at times can make individual independent variables appear to be statistically significant predictors. However, when all of the independent variables are considered simultaneously, and the covariance among them is taken into account, ones that initially appeared significant can become trivial. Conversely, some that were not initially significant can become so. Given this possibility, the second stage of the investigation involves the entry of only the 1979 data $^{3}$ in a regression analysis. ${ }^{4}$ In this procedure the dependent variable-constitutional options-is a factor score derived from a factor analysis of the structure underlying Québécois responses to the questions on constitutional alternatives. ${ }^{5}$ The independent variables are the

2. The 1974, 1979, and 1980 Canadian National Election studies and the Quebec Referendum Study combine national cross-sectional and panel data to study short and long term forces affecting voting and other types of political behavior in Canada. The 1974 study entailed post-election personal interviews with a national sample of 2562 respondents. Of those interviewed shortly after the July 8, 1974, election, 1295 were reinterviewed after the May 22, 1979, federal election. Interviews also were conducted with a new representative cross-sectional sample of 1467 respondents, yielding a total sample of 2762 cases. Following the February 18, 1980, federal election, 1748 respondents in both the panel and cross-section samples were contacted by telephone and reinterviewed. Quebec respondents again were contacted by telephone during the period immediately before and after the May 20, 1980, Referendum and 325 of these were successfully reinterviewed. Technical information on the design of the studies can be found in H. CLARKE, J. JENSON, L. LeDuc \& J. Pammett, Political Choice in Canada 397-400 (1979) [hereinafter cited as Clar Ke]; and LeDuc, Clarke, Jenson \& Pammett, A National Sample Design, 7 CaN. J. Pol. ScI. 701 (1974).

3. Only the 1979 data are used because they contain responses to questions that are not included in the 1980 study.

4. Regression analysis is a widely used statistical technique for estimating the functional relationships of a number of independent variables to a dependent variable. It is particularly useful for current purposes since it enables us to isolate the effects of individual independent variables, by controlling their shared variation. For a more extensive illustration of the usage of this technique, see S. CHATTERJEE \& B. PRICE, REGRESSION ANALYSIS BY EXAMPLE 1-18 (1977).

5. Factor analysis enables an investigator to reduce a large number of variables into a much smaller set of factors. More specifically, "[g]iven an array of correlation coefficients for a set of variables, factor analytic techniques enable us to see whether some underlying pattern of relationships exists such that the data may be 'rearranged' or 'reduced' to a smaller set of factors or components that may be taken as source 
aforementioned predictors (i.e., ethnicity, age, partisanship, socioeconomic status, and level of education) and four attitudinal variables-perceptions of government's impact on one's well-being, perceptions of costs and benefits of federalism to Quebec, federal-provincial orientations, and affective feelings toward the Canadian political community.

Age is measured in years and education in terms of years of schooling completed. The latter has three categories-elementary school, high school, and university. The ethnicity variable has two categories, Francophones and nonFrancophones. The socioeconomic status variable is a scale estimated by Bernard Elishen ranging from 14.41 to $75.32 .^{6}$ The federal-provincial orientation variable derives from responses to two questions regarding the level of government (federal versus provincial or local) considered by the respondent to be most important and closest to him and his family." The variable assessing perceptions of government's impact on one's well-being is derived from responses to a series of questions that produce an index assigning lowest scores to respondents who are very dissatisfied with their general and material well-being and hold government responsible for their condition. Highest scores are given to people holding the opposite views. ${ }^{8}$ The costs and benefits of federalism variable is derived from responses to questions about the manner in which the federal system is perceived to distribute costs and benefits to the several provinces. An index of costs and benefits was constructed by summing the number of times a respondent stated that Quebec bears unfair costs or receives less than a fair share of benefits. ${ }^{9}$ The partisanship variable is a measure of the direction and intensity of provincial partisanship and was generated from responses to standard Michigan Center for Political Studies-type questions. The partisanship scale ranges from "very strong Parti Québécois" to "very

variables accounting for the observed interrelations in the data." N. NiE, C. HuLL, J. JENKINS, K. STEINbrenner \& D. Bent, Statistical Package for the Soclal Sciences 469 (2d ed. 1975) [hereinafter cited as NiE].

6. Blishen \& McRoberts, A Revised Sacioeconomic Index for Occupations in Canada, 13 CAN. REv. Soc. \& ANTHROPOLOGY 71-80 (1976).

7. Responses to the following two questions were used: (1) As far as you are concerned personally, which government is most important in affecting how you and your family get on, the one in Ottawa, the provincial government here in Quebec, or the local government in _ ? (2) Would you say that you feel closer to the federal government in Ottawa, or to the provincial government here in Quebec? For each of these questions, federal responses were scored +1 , provincial responses -1 , and other responses (local, both, etc.) were scored 0 . Scores were summed to yield a 5 point index $(+2$ to -2$)$.

8. Judgments of government's impact on personal well-being were measured by asking respondents whether: (a) they were satisfied or dissatisfied with their economic condition and lives more generally; and (b) government had any effect on their condition. Satisfaction-dissatisfaction responses were scored as follows: very satisfied $=+2$; fairly satisfied $=+1$; a little dissatisfied $=-1$; very dissatisfied $=-2$. These scores were multiplied by government's perceived impact responses, which were scored as follows: a great deal $=2$; some $=1$; not much $=0$. The resulting index that was generated ranges from +4 to -4 . $A$ comparable index was generated for general life satisfaction, and the two measures were summed to yield an overall index with scores ranging from +8 to -8 . See Kornberg, Clarke \& Stewart, Federalism and Fragmentation: Political Support in Canada, 41 J. PoL. 889 (1979) [hereinafter cited as Kornberg].

9. Assessments of the distribution of costs and benefits of federalism were solicited with the following questions: (1) In your opinion, are some of the provinces bearing more of the costs of governing Canada? (If "yes") Which provinces are these? (2) What about benefits? Would you say that some provinces receive more than their fair share of the benefits of being part of Canada? (If "yes") Which provinces are these? For further details, see Kornberg, supra note 8, at 893-94. 
strong other".10 Finally, affective feelings for the Canadian political community are ascertained by a thermometer scale. Respondents are given a picture of a thermometer that is a 100-point scale and asked how favorably they feel about Canada. On the thermometer the 50 degree mark is designated as the neutral point with scores above and below reflecting positive and negative feelings. Since respondents may use the thermometer scale somewhat differently, the scores are standardized.

\section{III \\ EXPECTATIONS}

Initial expectations were that Francophones, especially younger Francophones who were identified with the Parti Québécois, would be most in favor of sovereignty association or outright independence and most opposed to the status quo and renewed federalism. Older Québécois who were neither Francophones nor Parti Québécois partisans would hold the opposite views. It further was assumed that Québécois who were attuned to both federal politics and the federal government, felt that the federal system had not adversely affected Quebec's fortunes, were satisfied with their economic and more general life statuses and felt that government had had a positive impact on them, and ascribed strong support to Canada as a political community also would be most in favor of renewed federalism and the status quo and most opposed to sovereignty association and independence. Finally, no assumptions were made about the impact of education and social class because the effects of those factors on Québécois constitutional positions might be mediated by Parti Québécois partisanship. ${ }^{11}$

\section{IV}

\section{Findings}

Even a cursory inspection of the data derived from the 1979 national election and the 1980 referendum studies suggests that the Parti Québécois leaders, if they have accomplished nothing else, have successfully shifted the parameters of the debate over Quebec's future. For a majority of the population, the issue is not whether Quebec's status in confederation should change $60 \%$ were opposed to the maintenance of the status quo in 1979 and $67 \%$ in 1980) but, rather, how extensive the change should be. Particularly striking is the fact that in $1979,54 \%$ of the non-

10. For provincial partisan identification, respondents were scored in the following manner: very strong Parti Québécois identification = 3; fairly strong Parti Québécois identification = 2; weak Parti Québécois identification or "leaning" toward the Parti Québécois = 1; non-identifier = 0; weak identification with or leaning toward another party $=-1$; fairly strong identification with another party $=-2$; and very strong identification with another party $=-3$.

11. Previous studies have indicated that the Parti Quebecois is to some degree a coalition of "top" and "bottom"- of young, well-educated, upper-middle class professionals and managers and older, less educated, lower status white and blue collar workers. See, e.g., Hamilton \& Pinard, The Bases of Parti Québécois Support in Recent Quebec Elections, 9 CAN. J. POL. SCI. 3 (1976); Pinard \& Hamilton, The Independence Issue and the Polarization of the Electorate: The 1973 Quebec Election, 10 CAN. J. OF POL. SCl. 215 (1977); Pinard \& Hamilton, The Parti Quebecois Comes to Power: An Analysis of the 1976 Quebec Election, 11 CAN. J. POL. SCI. 739 (1978). 
Francophone proportion of the population were opposed to the status quo. ${ }^{12}$ (See Table 1.)

It is clear that sovereignty association and independence are much more popular options among Francophones, the young, and those who identify with the Parti Québécois than they are among other elements in the population. (See Tables 1, 2 and 3.) It is also noteworthy that although approximately equal proportions of the population favor renewed federalism and special status for Quebec in 1979 , the percentage favoring the latter option remains relatively constant in the interim between the 1979 national election and the 1980 referendum, whereas the percentage favoring renewed federalism increases significantly during the same period. (See Table 1.) Growth in support for sovereignty association also outstrips growth in support for special status. For example, $61 \%$ of the Parti Québécois identifiers favor sovereignty association in 1979 and by 1980 fully $88 \%$ are in favor. In addition, Francophone support for sovereignty association increases from $29 \%$ to $51 \%$ during the year. (See Table 1.) In contrast, support for special status remains unchanged among "Pequiste" identifiers and increases by only $8 \%$ among Francophones.

12. Although opposition to the status quo among non-Francophones declined somewhat at the time of the Referendum (48\%), it seems clear that this option will become increasingly less viable in the future. 


$$
\begin{aligned}
& \text { 흉ำ } \\
& \text { 爮+\& }
\end{aligned}
$$

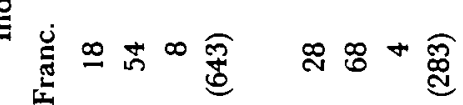

范

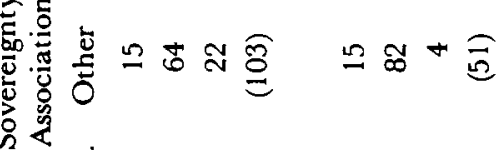

$$
\text { 樆 }
$$

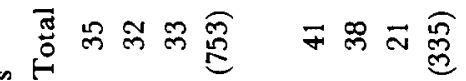

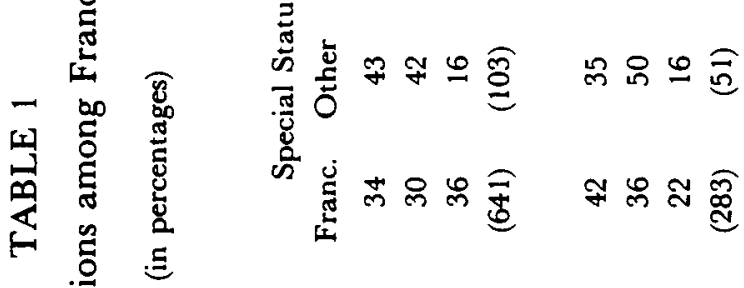

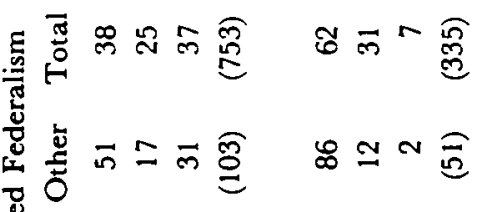

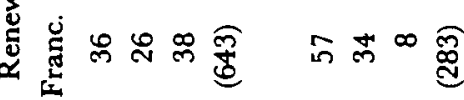

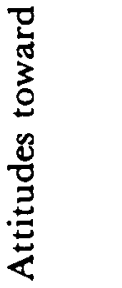

$\frac{9}{2}$

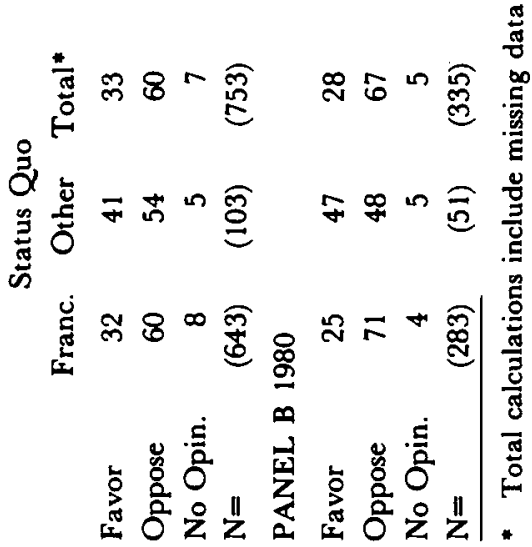




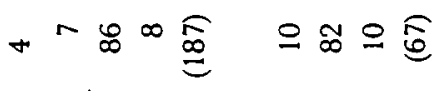

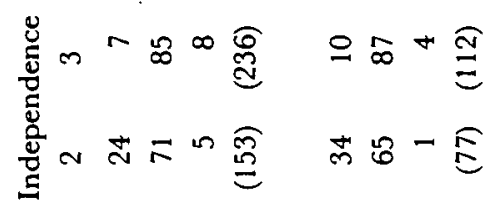

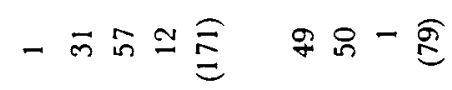

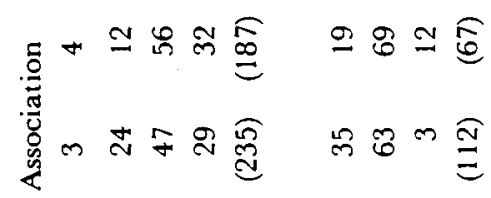

$$
\begin{aligned}
& \text { 高 }
\end{aligned}
$$

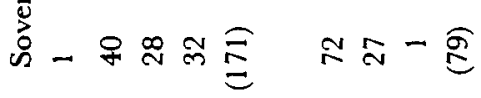

$$
\begin{aligned}
& \text { - }
\end{aligned}
$$

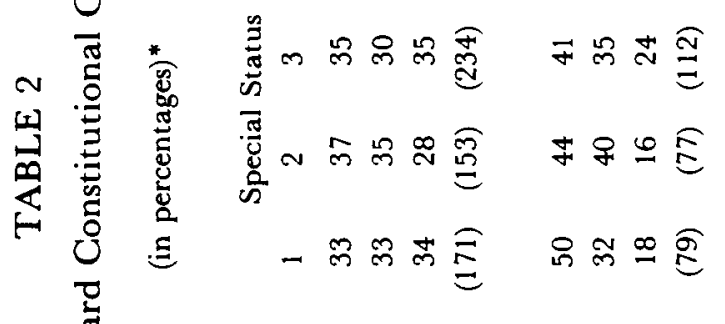

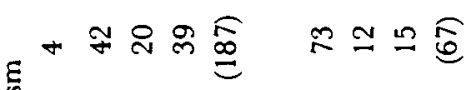

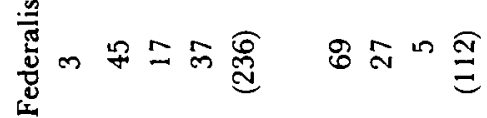

$$
\begin{aligned}
& \text { 遌 }
\end{aligned}
$$

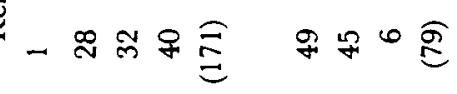

$$
\begin{aligned}
& \text { - भ भ }
\end{aligned}
$$

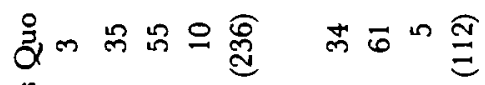

$$
\begin{aligned}
& \text { 总 }
\end{aligned}
$$

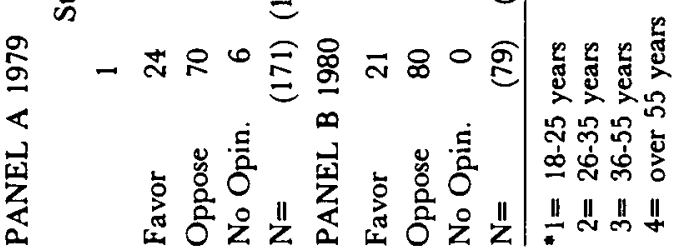




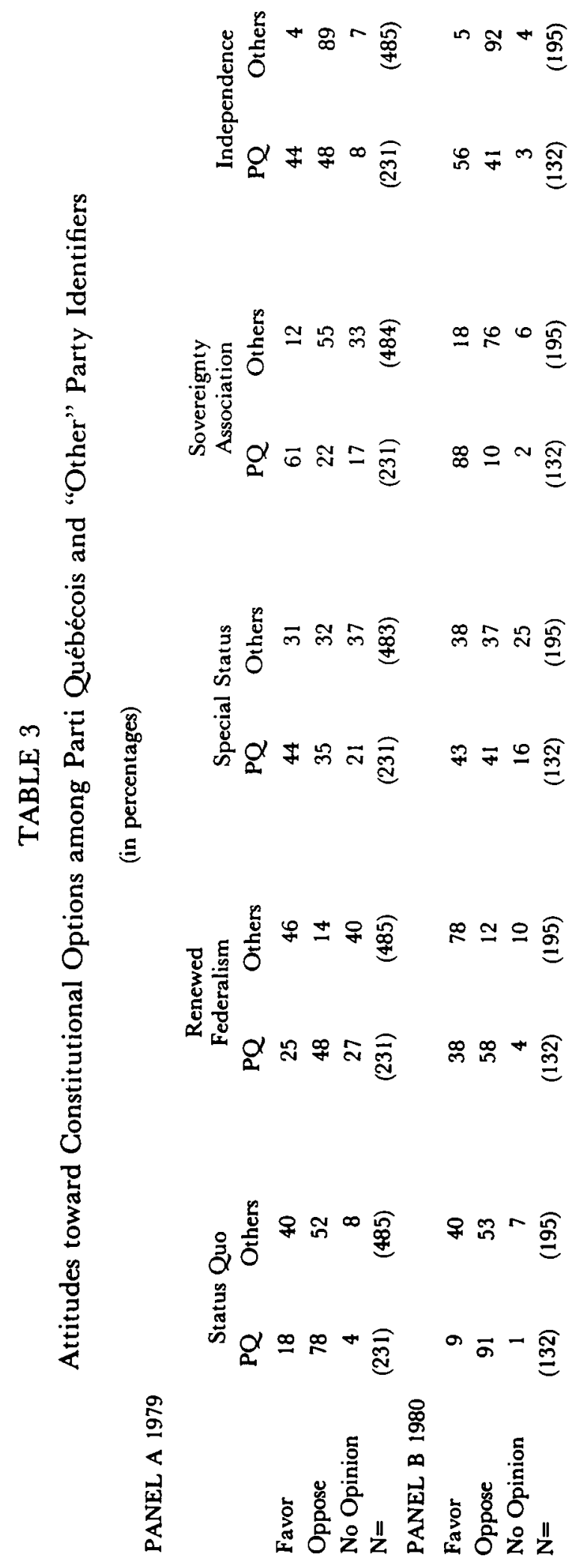


When positions on constitutional options are cross-tabulated with two measures of social class (i.e., socioeconomic status and level of education), the data indicate that in 1979 respondents with lower socioeconomic status and education levels were more likely to have no opinions on such relatively vague options as renewed federalism and sovereignty association. In 1980, however-probably as a consequence of the vigorous referendum campaign-the percentage of respondents without opinions on these alternatives declined dramatically. (See Tables 4 and 5.)

Some interesting differences emerge in the associations between socioeconomic status and level of education on the one hand, and constitutional options on the other, when the effects of the ethnic backgrounds of respondents are controlled. Among non-Francophones, increases in socioeconomic status and educational levels are accompanied by a.corresponding increase in opposition to sovereignty association. Among Francophones, however, higher socioeconomic status and educational levels are associated with an increased preference for the independence option. ${ }^{13}$ These cross-tabulations complete the first stage of the investigation. The results of the second stage, employing a regression analysis, are presented below.

\section{TABLE 4}

Attitudes toward Constitutional Options by Socioeconomic Status

$$
\text { (Blishen Score)* }
$$

PANEL A 1979

$$
\text { (in percentages) }
$$

\begin{tabular}{|c|c|c|c|c|c|c|c|c|c|c|}
\hline & \multicolumn{2}{|c|}{ Status Quo } & \multicolumn{2}{|c|}{$\begin{array}{l}\text { Renewed } \\
\text { Federalism }\end{array}$} & \multicolumn{2}{|c|}{$\begin{array}{l}\text { Special } \\
\text { Status }\end{array}$} & \multicolumn{2}{|c|}{$\begin{array}{l}\text { Sovereignty } \\
\text { Association }\end{array}$} & \multicolumn{2}{|c|}{ Independence } \\
\hline & Low & High & Low & High & Low & High & Low & High & Low & High \\
\hline Favor & 35 & 26 & 31 & 49 & 29 & 40 & 17 & 33 & 11 & 19 \\
\hline Oppose & 53 & 72 & 20 & 32 & 23 & 45 & 36 & 55 & 74 & 77 \\
\hline No Opin. & 12 & 2 & 49 & 19 & 47 & 15 & 47 & 12 & 14 & 4 \\
\hline$N=$ & (189) & (137) & (189) & (137) & (189) & (137) & (188) & (137) & (189) & (137) \\
\hline \multicolumn{11}{|c|}{ PANEL B 1980} \\
\hline Favor & 34 & 16 & 51 & 68 & 34 & 38 & 39 & 46 & 17 & 30 \\
\hline Oppose & 58 & 83 & 34 & 30 & 40 & 45 & 51 & 53 & 76 & 66 \\
\hline No Opin. & 8 & 1 & 14 & 1 & 25 & 17 & 10 & 1 & 7 & 4 \\
\hline $\mathbf{N}=$ & (71) & (77) & (71) & (77) & (71) & (77) & (71) & (77) & (71) & (77) \\
\hline
\end{tabular}

- The middle categories have been omitted for clarity

13. Data are not presented in tabular form. 


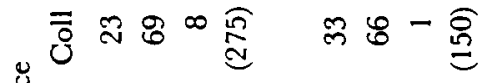

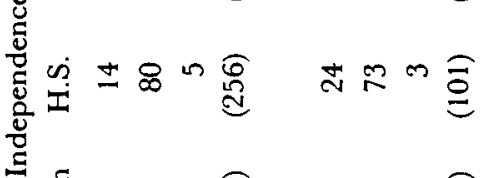

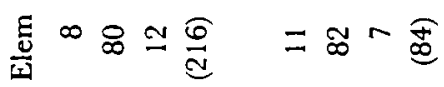

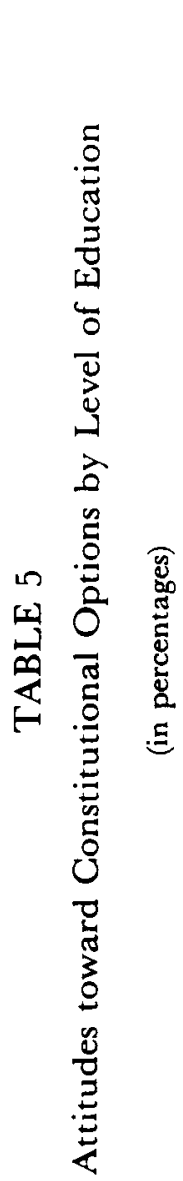

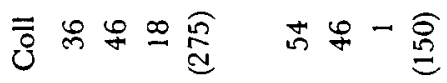

$$
\begin{aligned}
& \text { 离兽山 }
\end{aligned}
$$

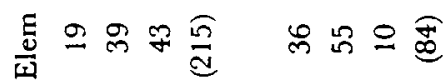

$\overline{\bar{\delta}}$

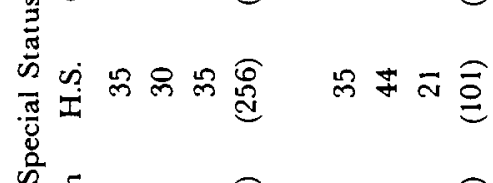

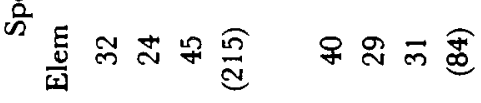

ह

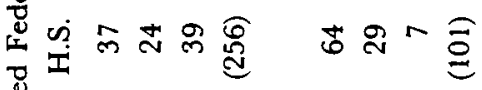
造焉

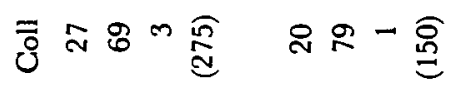

$$
\begin{aligned}
& \text { 岂 }
\end{aligned}
$$

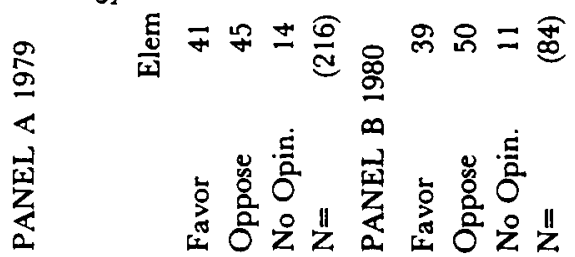




\section{REGRESSION}

The regression technique enables an investigator to assess net relationships between each of a number of predictors and a dependent variable under a condition in which the effects of all other predictors are controlled. As noted above, in the current investigation the predictor variables are age, ethnicity, education, socioeconomic status, provincial partisanship, affective feelings for Canada, federal-provincial orientations, perceptions of government's impact on personal wellbeing, and perceptions of the costs and benefits to Quebec of federalism. The dependent variable is generated by a factor analysis which produces two scores with Eigen values greater than one which measure the attitudinal structures underlying Quebecers' positions on constitutional alternatives. ${ }^{14}$ The first factor score loads most heavily on three options: renewed federalism, sovereignty association, and independence. The second score loads heavily only on special status.

An examination of the results obtained when the first factor score is used as the dependent variable indicates that together the several predictors are able to explain $49 \%$ of its variance. Age, provincial partisanship, feelings toward the Canadian political community, perceptions of the costs and benefits of federalism to Quebec, and orientations to federal as opposed to provincial politics are all significant predictors of people's constitutional preferences. Interestingly, however, ethnicity is not a significant predictor. Neither are levels of education, socioeconomic status, nor perceptions of government's impact on personal well-being significant predictors when the effects of the other variables are controlled. (See Table 6.)

The direction of the signed Betas ${ }^{15}$ indicates that older Quebecers, people oriented towards federal politics, those who feel Quebec has paid and received its "fair share" of federal costs and benefits, people who feel positively about the Canadian political community, and who are not identified with the Parti Québécois, are most in favor of renewed federalism and, to a lesser extent, the status quo. Conversely, younger elements in the population, those oriented toward provincial politics, who feel federalism has impacted negatively on Quebec, have neutral or negative feelings about the Canadian political community, and are identified with the Parti Québécois, are also the strongest supporters of sovereignty association and, to a lesser extent, of outright independence.

14. An Eigen value is a measure of the relative importance of a particular factor (unobserved variable) in an explanation of the total variance of the observed variables. Since the variance explained by any single variable will have a minimal value of one, the general rule for the retention of factors is that they explain more variance than any single variable, and hence have an Eigen value greater than one. For an elaboration of this point see NIE, supra note 5, at 468-514; J. KIM \& C. MUELLER, INTRODUCTION TO FACTOR ANALYSIS 49 (1978).

15. In multiple regression analysis, a Beta weight (standardized regression coefficient) is calculated to estimate the amount of variance in the dependent variable that is explained by any one of several independent variables, with each of the latter being assigned a unique Beta. Since multiple independent variables are often measured in different units, standardizing the regression coefficients by assigning them each a unit of one facilitates comparison of their relative effects. The sign of the Beta refers to the direction of the relationship. For example, a positive Beta indicates that high values on an independent variable correspond to high values on the dependent variable. For further details see NiE, supra note 5 , at 325 . 
TABLE 6

Multiple Regression Analysis of Attitudes toward Constitutional Options

Predictor Variables

Provincial Partisanship

Affect for Canada

Federal-Provincial

Orientations

Perceptions of Costs and

Benefits to Quebec of

Federalism

Age

Ethnicity

Education

Socioeconomic Status

Perception of Gov'ts

Impact on Personal Well

Being
(Factor 1)

\begin{tabular}{cr}
\multicolumn{2}{c}{ Constitutional Options Scores } \\
$\mathbf{r}$ & Beta \\
.64 & $.38^{*}$ \\
-.52 & $-.19^{*}$ \\
-.49 & $-.14^{*}$ \\
& \\
.37 & $.12^{*}$ \\
& \\
-.35 & $-.13^{*}$ \\
.19 & .02 \\
.17 & .02 \\
-.09 & -.05 \\
-.02 & -.01 \\
& \\
$\mathrm{R}=.70$ & $\mathrm{R}^{2}=.49$
\end{tabular}

* $\mathrm{p} \leq .001$

The second factor score was subjected to a similar analysis. Virtually none of the variance in the dependent variable is explicable, however, because none of the predictor variables_not even provincial partisanship-is a statistically significant correlate. One explanation for the lack of correlation is that the factor analysis employs a varimax rotation. ${ }^{16}$ Because of this rotation, significant predictors of first factor scores cannot be similarly strongly correlated with second factor scores. A second reason for the lack of correlation is suggested by the cross-tabulations presented in Tables 1-5. The data in these tables indicate that special status is an option that receives approximately the same degree of minority support from every group in Quebec. Hence, there is relatively little variance in the dependent variable for the regression analysis to explain.

To recapitulate, data derived from a 1979 national election study and a 1980 referendum study were used to assess a number of expectations regarding the distribution of Québécois support for five constitutional alternatives. The data indicate a sharp increase in support for renewed federalism and sovereignty association

16. In factor analysis, one has the option of specifying either unrotated or rotated factors. If the unrotated factors are expected to be theoretically meaningful, which is usually not the case, then no rotations are performed. However, the rotation of factors is usually desirable since it simplifies the factor structure. NiE, supra note 5, at $\mathbf{4 8 2}$. Varimax rotation, the most commonly used, maximizes the variance of the squared loadings in each column; the axes are rotated at a 90 degree angle (on the assumption that the factors are uncorrelated) until they more closely intersect the clusters of variables, thereby producing a simpler solution. J. KIM \& C. MUELLER, supra note 14, at 49-50. Part of the results are a statistical artifact because each of the factors after the first explains only residual variance. 
during the year, a more modest increase in support for independence and special status for Quebec, and a decline in support for maintaining the status quo. The results of a regression analysis are consonant with most of the initial expectations. Thus, the greatest support for renewed federalism and, to a lesser degree, the status quo, comes from Québécois who: identify with other than the Parti Québécois; are older; have strong, positive feelings about the Canadian political community; are oriented toward federal rather than provincial politics; and perceive that Quebec has paid its fair share of the costs and has received its fair share of the benefits of federalism. In contrast, strongest support for sovereignty association and, to a lesser degree, independence, comes from Québécois with the opposite attributes.

\section{Discussion}

The analyses above suggest a number of conclusions, two of which are particularly noteworthy. First, it seems clear that the Quebec electorate is not a kind of lumpenproletariat. Supporting this conclusion is the dramatic decline during the year in the proportion of respondents without an opinion on the two most ambiguous constitutional options, renewed federalism and sovereignty association. Moreover, the decline occurred even among the least educated segment of the public. For example, in the 1979 survey, $50 \%$ of the respondents with an elementary school education or less had no opinion about renewed federalism and $43 \%$ had no opinion about sovereignty association. By 1980 , however, the proportion without an opinion on those two options had declined to $17 \%$ and $10 \%$. (See Table 5.) Thus, it can be inferred that the Quebec electorate, including the segment which in most democracies is least attentive to and knowledgeable about politics, ${ }^{17}$ became increasingly politically sophisticated as it was exposed to information during the course of the referendum campaign. Adding force to this conclusion is the result of the factor analysis. The latter indicates-despite any confusion that may have resulted from receiving conflicting information from political leaders ${ }^{18}$ - that there is a definite underlying structure to Québécois positions on

17. There is a large body of literature documenting the relationship between education, on the one hand, and political interest, sophistication, and activity, on the other. One of the earliest and clearest expressions of this relationship was presented by Almond and Verba. They argued that "[a]s in most other studies of political attitudes, our data show that educational attainment appears to have the most important demographic effect on political attitudes. Among the demographic variables usually investigatedsex, place of residence, occupation, income, age, and so on-none compares with the educational variable in the extent to which it seems to determine political attitudes. The uneducated man or the man with the limited education is a different political actor from the man who has achieved a higher level of education." G. Almond \& S. Verba, The Civic Culture 316-16 (1965). For a discussion of the effects of education on levels of political information and sophistication, see Converse, The Nature of Belief Systems in Mass Publics, in IDEOLOGY AND ITS DisconTENTS 206-61 (1964). Regarding the former, Converse notes that "[i]t is well established that differences in information held in a cross-section population are simply staggering, running from vast treasuries of well organized information among elites interested in the particular subject to fragments that could virtually be measured as a few bits in the technical sense . . . . Of course, the ordering of individuals on this vertical information scale is largely due to differences in education." Id. at 212 . For Canadian data, see ClARKE, supra note 2, at 288.

18. For example, in his paper, Alan Cairns observes that when federal and provincial political leaders refer to a concept such as renewed federalism, they are talking about quite different things. To provincial leaders, renewed federalism is regarded as a constitutional status that will provide them with the opportu- 
the five constitutional alternatives.

A second conclusion that merits comment is rather ominous for the future of a Canadian political community that includes Quebec. Analyses indicate that the strongest support for sovereignty association and independence, the two constitutional options posing the greatest threat to the Canadian political community, comes from a segment of the public which is young, cares little about federal politics and is disenchanted with the operation of the federal system. Since Québécois with these attributes ${ }^{19}$ also tend to be disproportionately identified with a political party whose avowed raison d'être is independence-outright or in stages-it can be argued that their disaffection with current arrangements goes beyond unhappiness with the political regime and extends to the national political community itself.

Of course, it is arguable that these data reflect a life cycle rather than an agecohort effect. ${ }^{20}$ Therefore, as this group ages, its affection for the Parti Québécois and for sovereignty association or independence could wane, while its support for system-maintaining options such as renewed federalism could increase. Although the necessary longitudinal data from which reliable estimates could be drawn are lacking, a life-cycle interpretation would be congruent with the finding that the strongest support for renewed federalism and, to a lesser extent, the status quo, comes from older Francophones who are oriented toward federal politics, feel the costs of federalism to Quebec have not been excessive, are identified with the provincial Liberal party, and feel strongly and positively about Canada.

However, a life cycle interpretation, although plausible, is not likely to be accurate because it rests heavily on the assumption that support for the Parti Québécois will erode in the future. As a recent analysis by Harold Clarke makes abundantly clear, the opposite has been and will likely continue to be the case. ${ }^{21}$ Employing panel data gathered in a series of surveys conducted since 1974, Clarke's analysis reveals that the Parti Québécois has more than doubled its percentage of partisan supporters since 1974 .

It has achieved these substantial net gains in the size of its group of party identifiers by two processes: by converting former adherents of all other major parties, and by benefitting hand-

nity to expand their influence over the operation of the federal government. For archetypal federalists such as Prime Minister Pierre Elliot Trudeau, renewed federalism means a condition under which Canadians, irrespective of their province of residence, will regard Ottawa rather than their provincial capitals as "their government." Cairns, supra note 1.

19. For an extended discussion of the relationships among these variables and their likely impact on the politics of Quebec, see Clarke, The Parti Québecois and Sources of Partisan Realignment in Contemporary Quebec, 45 J. Pol. 64 (1983).

20. The impact of the Depression on young Americans is frequently cited to illustrate an age cohort effect. For example, a substantial proportion of the people who came of age during the Great Depression retained throughout their lifetime many of the attitudes (including their Democratic partisanship) and opinions they had formed as young people, despite the fact that in many cases their socioeconomic status improved significantly as they aged. Moreover, through the process of socialization, they transmitted many of these attitudes and opinions to their children. In Quebec's case, one might assume that the younger supporters of an independent Quebec will transmit their preferences to their children, while the natural attrition that occurs in any population as it grows older will increasingly diminish the level of support for a federal state in which Quebec remains an integral part. A discussion of the techniques necessary to separate life cycle, cohort, and period effects can be found in N. GLENN, COHORT ANALYSIS (1978).

21. Clarke, supra note 2, at 82-84. 
Page 71: Autumn 1982]

somely by the replacement of older generations of Quebecers by younger cohorts of newly eligible voters who are favorably disposed toward the party and its goals. ${ }^{22}$

Therefore, it would appear-despite the impressive April 17, 1982, ceremonies on Parliament Hill and the subsequent adoption of a new constitution-that the constitutional crisis will continue.

22. ClaRkE, supra note 2 , at 67 (emphasis added). 
